\section{THE NATIONAL INSURANCE ACT.}

The General Medical Council and "OWN ArRangements" : A MEMORANDUM BY Sir Donalid MacAlister.

A MEMorandum was presented by Sir Donald MacAlister, President of the General Medical Council, to the National Insurance Act Committee and the Executive Committee of the Council, on Monday last, Feb. 23rd, when these committees had under their consideration all the circumstances under which insured persons are entitled to make their own arrangements for the receipt of medical benefit. The memorandum runs as follows :-

The President desires to remind the committees that in November, 1913, he received and transmitted to members certain communications in which it was alleged that one or more Local Insurance Committees had entered into or sanctioned forms of agreement with unqualified persons, by which the latter undertook to provide medical attendance and medicines to insured persons who were permitted to " make their own arrangements" for medical treatment under the National Insurance Act. Owing to his illness the President was unable to be present at the meetings of the National Insurance Act Committee at which these com. munications were considered. The minutes of the meetings, at which Dr. Langley Browne acted as chairman, were laid before the Council at its November session and approved. The minutes showed that the committee were of opinion that the action taken by one at least of the Local Insurance Committees raised questions of grave importance as to the relation of the Medical Acts to certain Regulations made under the Insurance Acts. As it appeared doubtful whether the Local Committee in question was acting with the official sanction of the Insurance Commissioners, inquiries were addressed to the latter, and, as will be seen from the annexed correspondence, objections of a legal character were urged in the public interest against the Local Committee's proceedings.

The Chairman of the National Health Insurance Commission for England (Sir Robert L. Morant) met the Council's committee on Nov. 27th, 1913, and after a statement made by Dr. Norman Walker, at the request of the committee, in regard to the changes in their Regulations which it was desired that the Commissioners should make in respect of unqualified persons, a discussion took place on the questions thus raised. Sir Robert Morant agreed that the objections that had been raised to some aspects of the action of the Local Committee were valid, and stated that its procedure had apparently been adopted under a misapprehension. At the same time it was the case that, as had been explained by the Government during the consideration of the Bill in Committee in the House of Commons, under the provisions of the present Section 15 (3) it was open to Insurance Committees, if they thought fit, to allow insured persons who so desire to make their own arrangements, subject to certain conditions, with persons not medically qualified, and to receive a contribution towards the cost thus incurred. The 1913 Regulations contained no reference to this matter, and therefore made no special provision for such cases. It was thus impossible for the Commissioners to prevent the recurrence in those cases of action such as that referred to without issuing new and explicit Regulations dealing with the case of arrangements with unqualified persons.

Sir Robert Morant stated that the Commissioners, in drawing up the amended Regulations and Memoranda for 1914 (which were already in course of preparation) would be prepared to meet the wishes of the Council in regard to the objections in question. By making the requisite amendments in the Regulations and issuing instructions to Local Committees they would set forth clearly that the procedure to be adopted in the case of "own arrangements" made by insured persons with qualified practitioners was not applicable to the case of "arrangements" which certain insured persons might be permitted by the Insurance Committee to make, on their own responsibility, with unqualified persons. It was beyond question that, in the case of arrangements made by insured persons with unqualified persons, some of the conditions of the Fxchequer Grant-for instance, the undertaking to give domiciliary treatment for tuberculosis in accordance with the Local Government Board Order-could not be fulfilled. As to a point which had been raised about medical certificates furnished to Approved Societies by insured persons when claiming sickness benefit, Sir Robert Morant stated that no question arose as to treating any statement of an unqualified person as a medical certificate. The rules of Approved Societies require the society to be satisfied by a medical certificate or other evidence of incapacity before admitting the claim to sickness benefit. Any such statement will be merely evidence which the society may have to consider in adjudicating upon a claim for sickness benefit in accordance with its rules. Responsibility for weighing that evidence rests with the society.

After further discussion, Sir Robert Morant repeated that the Commissioners, in the revision of the Regulations then in progress, would gladly give the fullest possible effect to the wishes then expressed to him on behalf of the Council, and in particular would endeavour to secure that the memoranda and official forms now to be issued by the Commissioners on this subject, for the guidance of local committees and others concerned, should be worded with a view to avoid misunderstanding. Every effort would be made to exclude phrases which might seem to afford occasion for any contravention of existing statutes bearing on the subject. Nor would the Commissioners approve any procedure which failed to make the necessary discrimination between the unqualified person and the practitioner who is "duly qualified " according to law.

The letter written by the President at the request of the Council in order to give formal expression to its views, and the letters sent by the Commissioners in reply thereto, are appended. The new Regulations issued by the Commissioners in pursuance of the above-mentioned discussion have been circulated to members of the Council, and published for general information. The new Memorandum (191/I.C.) of the Commissioners, explaining more fully the purport of Regulation 44, is circulated herewith. ${ }^{1}$

These documents appear to the President to give substantial effect to the wishes which the Council requesteed him to express to the Commissioners. He is satisfied that the Commissioners fully apprehend that the Council attaches great importance to its contention that nothing should be done, by administrative action, which would tend to defeat the purpose of the Legislature in framing the Medical Acts-namely, "to enable persons requiring medical assistance to distinguish qualified from unqualified practitioners"; or which might be deemed to confer official "recognition" on persons who according to law are "unqualified" and are prohibited from assuming the status" and responsibilities of registered medical practitioners. He submits the Regulations and Memorandum to the Executive Committee in the belief that his colleagues will desire to acknowledge cordially the readiness the Commissioners have shown to consider the representations made to them, and to remove difficulties which have arisen in connexion with the local administration of the National Insurance Act.

Feb. 23rd, $1914 . \quad$ Donald Madalister, President.

The following are the appended letters :-

\section{A}

General Council of Medical Education and Registration of the United Kingdom,

$$
\text { 299, Oxford-street, London, W. }
$$

No. 34946. 9th December, 1913.

DeAR SIR RoBERT, -The General Medical Council has learned that one of the Local Insurance Committees has recently approved a form of agreement, between certain insured persons and a person who is not qualified under the Medical Acts, by the terms of which the latter undertakes to provide the insured persons with medical attendance and medicines, to give the domiciliary treatment included as a part of Sanatorium Benefit, and to furnish such certificates as may be required to enable the insured persons to obtain the several benefits of the National Insurance Act.

The Council has no reason to believe that the form of

1 The Memorandum of the Commissioners was published in

The LaNCET of Feb. 14th, p. 50 . 
agreement in question has received the official approval of the Commissioners ; and I am now, on behalf of the Council, writing to ask that the Commissioners should formally intimate their disapproval of it to the Local Insurance Committee.

The information in the possession of the Council makes it clear that the form of agreement employed in this case is appropriate only to an arrangement made with a legally qualified practitioner, and that some of the undertakings it contains cannot be legally carried out by an unqualified person. I am advised that such agreements are in fact invalid, inasmuch as they contravene the provisions and defeat the purpose of the Acts regulating medical practice in this country. If such action on the part of the Local Insurance Committees were to become general, it would moreover, in my opinion, defeat the objects of the National Insurance Act itself.

The Council is confident that the Commissioners will realise the importance in the public interest of the question of principle thus raised; and that they will take all proper steps both to bring to an end the procedure to which objection is taken and to inform the authorities who may be concerned that, in connexion with the administration of medical benefit, no valid agreement of the kind can subsist with an unqualified person.

I am, yours very faithfully,

(Signed) Donald MacAlister, President.

Sir Robert Morant, K.C.B.

National Health Insurance Commission. by-

A note of formal acknowledgment was followed

National Health Insurance Commission (England), Buckingham Gate, London, S.W., January 9 th, 1914.

Dear Str Donald MacAlister,-I write to say that we now have our new Medical Regulations practically completed containing paragraphs that will make it possible to deal, in the way that the General Medical Council indicated to be in their view desirable, with the various points about unqualified practitioners that were discussed at my meeting with your committee on 27th November ; and I shall hope in a few days to be able to send you, as we arranged, a draft of the explanatory Circular and Forms needed in this connexion. I will send you copies of the new Regulations directly any are available from the printer.

When you receive them you will see that the subsections of the new Section 44 (formerly Section 49) set out in separate paragraphs the procedure to be followed in the case of those insured persons on the one hand who make "own arrangements" with unqualified persons, and those on the other hand who make "own arrangements "with registered practitioners. The words "in such manner" in the new Section 24 (formerly Section 14) mean that a special form will be required for use in these cases. The separation of Subsection (2) from Subsection (1) of the new paragraph 44 in the new Regulations makes it clear that the committee does not have to institute any comparison between the treatment provided by the unqualified person and the treatment provided by the qualified practitioner. Furthermore, under the new wording of paragraph 44 (4) it will be necessary for the Insurance Committee to make plain in any "own arrangements" with unqualified persons that there are some things required as conditions of the Treasury grant, which the unqualified person will not be expected to do (for the reason, of course, that he is not qualified for doing them), without for that reason precluding all possibility of contributions being made by the Insurance Committee towards the insured person's expenditure in such cases.

With the new Regulations thus clear on these points I do not think we shall now find any particular difficulty in arriving at suitable means for giving effect to what your committee indicated, when we draft the explanatory Circular and Forms; but I shall be glad if you let me know of any points in the latter, when $I$ send them to you, which seem to you either not clear or inconsistent with what is in view.

I am, yours very truly,

ROBERT L. MoRANT.

On Jan. 19th Sir Robert Morant wrote, enclosing a copy of the New Regulations for Medical Benefit, and indicating that in Section 44 steps had been taken to make definite distinction between qualified practitioners and unqualified persons in the case of insured persons desiring to make their own arrangements; and on Feb. 14th the communication which follows was accompanied by the memorandum to Insurance Committees explaining generally the provisions of the Medical Benefit Regulations for 1914 , governing "own arrangements" under Section 15 (3) of the 1911 Act, both with registered practitioners and with unqualified persons. This memorandum was published in THE LANCET on that date through the courtesy of the Commissioners.

As regards the memorandum Sir Robert Morant writes to Sir Donald MacAlister :-

You will find, I think, that the two points which your Council pressed us to make explicit have been fully met, i.e. :-

(a) Attention has been unmistakably drawn to the distinction between "own arrangements" with registered practitioners and "own arrangements" with unqualified persons; and

(b) It has been made quite clear that Insurance Committees, in dealing with applications for "own arrangements" of the latter kind, are under no obligation to institute any comparison with the treatment afforded by a qualified doctor, or, indeed, to inquire into the nature or form of the proposals under consideration between the unqualified person and the insured person making his own arrangements.

Forms designed for the assistance of Insurance Committees in dealing with various types of applications for " own arrangements" have been prepared.

\section{London Panel Committee.}

The Insurance Commissioners have declared the following to constitute the first Panel Committee for the County of London to hold office until July 15th, 1914 :-

Battersea-Knox, A. W., Richards, Kensington - Atteridge, J. J., J. T.

Bermondsey - Jaynes, V. A. Lamer, R.

Rinnd - Jaynes, V. A., Lambeth - Cazenove, W. R.,

D. D.

Camberwell-Batten, G. B. (ViceChairman), Brenchley, A. D. Clatworthy, J. H., Esler, R., South, F. M. W.

Chelsea-Hudson, E., Orr, J. J. City of London-Scanlan, J. J., Strong, R. H.

Deptford-Gooding, C. G., Payne W. $\mathbf{H}$

Finsbury-Hockridge, T. G., Mac Gregor, R. D

Fulham - Coltart, G. H., MacBurney, J. $\mathrm{H}$

Greenwich-Corfe, R., Hogarth C. W.

Hackney-Keenan, T. F., Swan, A. $T$

Hammersmith - Butler, J. A., Davidson, W. A.

Hampstead-Cunnington, C. W. Taylor, E. Claude.

Holborn-Two vacancies.

slington-Jackson, J. E., Pateh, H. H. L., Sherry, J. J. A. Farman, R. J., Fraser, D. H., Taylor, $\mathbf{H}$ $\begin{array}{lll}\text { Lewisham-Donnellan, } & R . & V .\end{array}$

Paddington - Angus, J. A., Wiliams, J. O.

Poplar-Cardale, H. J., Paxton, J. t. Marslebone - Simpson, Pollock, Williams, R. Thorold. . Pancras-Fletcher, J. Oorbet Freyberger, L., Marshall, T.

Shoreditch-Two vacancies. Southwark-Denning, J. V. C., Smith, F. J. Porter. Stepney - Bernstein, M. M., Williums, W. O

toke Newington-Page, A. M., Welply, A. (Secretary).

Wandsworth - Biggs, A. C. B. MeMurtry, W., Roe, A. D. Thomas, $\mathrm{C}$.

Westminster - Roach, W. F., Starkie, R. F.

Woolwich-Clarke, J., Mair, A.

Wom en-Baker, Elizabet $h$, Bentham, Ethel.

Coöpted-Mills, H. H., Shaw, Lauriston E. (Treasurer)

\section{MEDICAL INCOMES UNDER THF NATIONAT} INSURANCE ACT.

In view of the system of payment adopted in lieu of the capitation system at Manchester, and of the resolution of the Insurance Committee in that city to limit incomes to be derived from panel practice to $£ 800$ a year, the sums realised during the first year of the working of the Act by the 300 medical men who have gone on the panel in Manchester are of interest. The largest individual income has been $£ 1980$; 14 practitioners have earned between 
$£ 1000$ and $£ 2000 ; 11$ between $£ 800$ and $£ 1000$; 32 between $£ 500$ and $£ 800$; and 47 between $£ 300$ and £500. Among those making incomes less than $£ 300$ per annum from panel practice, and particularly among 88 practitioners who have made less than $£ 50$, there are, no doubt, many who only attend as patients under the Insurance Act the servants and other dependents of their private patients in the wealthier neighbourhoods in which the bulk of their work is done. It will be interesting to set the above figures beside those that will record the working of the Act at Manchester during the current year. The figures given for panel practice at Leeds during 1913 form a useful comparison. Out of about 190 medical men on the panels there, 5 have made incomes of between $£ 1000$ and $£ 1500,7$ between $£ 800$ and $£ 1000,25$ between $£ 500$ and $£ 800$, and 27 between $£ 300$ and $£ 500 ; 30$ made less than $£ 50$. The above figures, of course, take no account of partnerships.

\section{Lancashire Insurance Commitiee.}

At a recent meeting of the Lancashire Insurance Committee a request was made by the Medical Benefit Subcommittee for Chadderton, Crompton, and Royton that medical men on the panel should be supplied with drugs and articles likely to be required upon an emergency, and should draw from such a stock in the event of insured persons applying to them for treatment at a time when druggists' shops were closed. The practice of making up prescriptions from their own stocks of drugs and keeping an account in accordance with the requirements of the Insurance Committee in order to obtain repayment was found to take up a great deal of time. On the other hand, the clerk to the Insurance Committee pointed out that considerable clerical work.would be entailed upon the committee if the proposed change were adopted. Eventually the subcommittee's recommendation was approved subject to the County Medical Committee and the County Pharmaceutical Committee being able to arrive at a working arrangement.

\section{出tedical allews.}

Untversity of Oxford.-The Philip Walker studentship in pathology, of the annual value of $\$ 200$ and tenable for three years, has been awarded to Charles Joseph Singer, D.M., Magdalen College. -The following medical degree has been conferred :-

D.M.-F. O. Stohr, Trinity College.

UNIVERSITY OF BRISTOL. - In the final examination for the degrees of M.B., Ch.B., held recently, the following candidate was successful :-

Maurice Charles Barber.

Lieutenant-Colonel Sir David Prain, director of Kew Gardens, was nominated by the President of the Board of Agriculture and Fisheries as one of the three representatives of that department at the International Conference on Phytopathology held at Rome this week.

The Campaign against Infant Mortality.On Feb. 24th the Queen attended a matinee at the Palace Theatre in aid of the Schools for Mothers in Fulham, Poplar, Shoreditch, and Stepney. These institutions are designed to give simple advice and instruction to working women, and are aimed directly against infant mortality. Originating in Ghent, these schools, which have now spread over Europe, were first tried in England at St. Pancras in 190'\%. They have proved a great success in many districts of London and in provincial towns, giving meals to women at a nominal cost for six months before and a year after the birth of a child, while medical men attend the schools twice a week, when babies are weighed and the mothers advised as to their own health and that of the children. Instruction in the making and mending of clothes is also given, the whole organisation being put at the disposal of the women for $1 d$. a month.

St. George's Hospital. - The annual dinner of the Hunterian Society of this hospital will be held on Friday, March 13th, at the Waldorf Hotel, and will be followed by a smoking concert. Tickets for the dinner will be $6 s$., exclusive of wine, and those desirous of being present should communicate with the honorary secretaries of the society at the hospital.

The Trained Nurses' Annuity Fund.-The Countess of Hardwicke, Lady Barlow, Lady Champneys, Mrs. Charles Balfour, and Miss Sidney Browne, members of the council of the Trained Nurses' Annuity Fund, have issued an appeal to nurses asking them to subscribe $1 d$. per month with the object of forming a benevolent fund. The address of the Trained Nurses' Annuity Fund, of which Princess Christian of Schleswig-Holstein is the President, is 73, Cheapside, London, E.C.

Association of Assistant Medical Officers OF ASYLUMS, ENGLAND AND WALES. - The executive of this association has issued a statement, which is being sent to all members and clerks of visiting committees of public asylums in England and Wales. The statement summarises the various directions in which the association. desires improvement in the terms and conditions of service of assistant asylum medical officers. These have been dealt with on several recent occasions in THE LANCET, and the case for reform was set out and discussed in a leading article on Jan. 10th last.

Conference on the Teaching of AnthropoLOGY.-Members of the Royal Anthropological Institute, representatives of the universities, and others interested in anthropology, met at the Drapers' Hall, London, on Feb. 19th, to discuss the practical application of the teaching of anthropology in the universities. Lord Selborne presided, and Sir Henry Craik, M.P., moved a resolution which approved the findings of the joint committee of the British Association and of the Institute, and declared that in the highest interests of the Empire the extension and organisation of the teaching of anthropology in the universities of Great Britain was necessary. Professor A. Keith, the president of the Institute, pointed out the lost opportunities for good which were the result of travellers to remote parts of the Empire not having sufficient knowledge of anthropology. The Institute wished to systematise all the information that it had gained and to place that information at the disposal of every university graduate. The resolution having been adopted, Sir Hercules Read moved that the chairman and members of the joint committee represent to the Prime Minister the views of the conference and ask for the appointment of an interdepartmental committee for advising as to the form in which the sympathy and support of the Government could be best expressed. Professor T. H. Warren seconded, and the motion, which was supported by I)r. W. L. H. Duckworth, Professor J. G. Frazer, and Dr. W. P. Herringham, was passed unanimously.

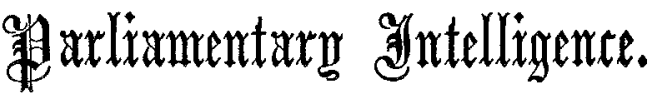

\section{NOTES ON CURRENT TOPICS. \\ Elementary Education (Defective and Epileptic Children) Bill.}

THE Flementary Education (Défective and Epileptic Children) Bill, which has been introduced into the House of Commons by Mr. PEAse, the President of the Board of Education, has been printed. It lays down that it shall be the duty of the local education authority for the purposes of the Elementary Education (Defective and Epileptic Children) Act, 1899 , to make stzitable provision for the education of children belonging to their area whose age exceeds sever years, and who are ascertained to be mentally defective within the meaning of the Act.

$$
\text { Inebriates Bill. }
$$

A Bill "to consolidate and amend the law relating to inebriates" has been introduced into the House of Commons 